
A $\mathbf{C}_{\text {ase }} \mathbf{S}_{\text {Tud }}$
FOOD SCIENCE
RESEARCH JOURNAL
ISSN-0976-1276 Visit us : www.researchjournal.co.in _Volume $10 \mid$ Issue 2 | October, 2019 | 232-236 DOI : $10.15740 / \mathrm{HAS} / \mathrm{FSRJ} / 10.2 / 232-236$

\title{
Health benefits of Cuscuta
}

\author{
Chungkham Chanu Malemnganbi and Namita Singh
}

Cuscuta reflexa is a parasitic plant, which belongs to the group of plants in the morning glory family, convolvulacea. It is commonly known as dodder plant, amarbel, akashabela and urisanamcha. Plant is rootless, perennial, slender threadlike, leafless climbing parasitic plant on shrubs or trees. The present article will collect the detailed description of synonyms, different name, habitat, scientific classification, chemical constituents from different literature as well as modern research journal. Present article deals with health benefits of Cuscuta. Further researches need to be done for popularization and utilization of this plant.

Key Words : Cuscuta, Amarbel, Uri sanamacha, Health benefits

How to cite this article : Malemnganbi, Chungkham Chanu and Singh, Namita (2019). Health benefits of Cuscuta. Food Sci. Res. J., 10(2): 232-236, DOI : 10.15740/HAS/FSRJ/10.2/232-236.Copyright@ 2019: Hind Agri-Horticultural Society.

Author for correspondence :

Chungkham Chanu Malemnganbi, Department of Food Science and Nutrition, College of Community Science, Central Agricultural University, Sangsanggre, Tura (Meghalaya) India

Email: malemnganbichungkham@gmail.com

Associate Authors' :

Namita Singh, Department of Food Science and Nutrition, College of Community Science, Central Agricultural University, Sangsanggre, Tura (Meghalaya) India

Email: drnam2007@rediffmail.com 